Florida International University

FIU Digital Commons

FIU Electronic Theses and Dissertations

University Graduate School

8-9-2000

\title{
A case study of the performing arts production program as a means of inclusive community building within the performing arts management domain
}

Kawachi Ahmon Clemons

Florida International University

DOI: $10.25148 /$ etd.FI14060856

Follow this and additional works at: https://digitalcommons.fiu.edu/etd

Part of the Music Commons

\section{Recommended Citation}

Clemons, Kawachi Ahmon, "A case study of the performing arts production program as a means of inclusive community building within the performing arts management domain" (2000). FIU Electronic Theses and Dissertations. 2387.

https://digitalcommons.fiu.edu/etd/2387 
FLORIDA INTERNATIONAL UNIVERSITY

Miami, Florida

A CASE STUDY OF THE PERFORMING ARTS PRODUCTION PROGRAM AS A MEANS OF INCLUSIVE COMMUNITY BUILDING WITHIN THE PERFORMING ARTS MANAGEMENT DOMAIN

A thesis submitted in partial fulfillment of the

requirements for the degree of

MASTER OF MUSIC

In

PERFORMING ARTS PRODUCTION

By

Kawachi Ahmon Clemons

2000 
To: Dean Arthur W. Herriot

College of Arts and Scienes

This thesis, written by Kawachi Ahmon Clemons, and entitled Creative uses of the Arts in Building the Inclusive Community, having been approved in respect to style and intellectual content, is referred to you for judgment.

We have read this thesis and recommend that it be approved.

Mark Nerenhausen

Michael J. Wagner

Karen Fuller, Major Professor

Date of Defense: August 9, 2000

The thesis of Kawachi Ahmon Clemons is approved.

Dean Arthur W. Herriot College of Arts and Sciences

Dean Richard L. Campbell Division of Graduate Studies

Florida International University, 2000 


\section{DEDICATION}

I dedicate this thesis to my grandfather, Moses Clemons, Sr. 


\section{ACKNOWLEDGEMENTS}

I wish to thank the members of my committee for their support and patience. Their gentleness has been greatly appreciated. In addition, I would like to give a special thanks to Dr. Lawrence C. Howard for giving the understanding to what means to build inclusively. Finally, I would like to thank my mentor, Dr. Deryl G. Hunt. From the beginning, he possessed the faith and diligence in mentoring me to ensure this work was completed with excellence. 


\title{
ABSTRACT OF THE THESIS \\ A CASE STUDY OF THE PERFORMING ARTS PRODUCTION PROGRAM AS A MEANS OF INCLUSIVE COMMUNITY BUILDING WITHIN THE PERFORMING ARTS MANAGEMENT DOMAIN
}

\author{
by \\ Kawachi Ahmon Clemons \\ Florida International University, 2000 \\ Miami, Florida \\ Karen Fuller, Major Professor
}

The problem examined in this study involved the lack of inclusiveness within upper level positions in the performing arts production arena. Traditionally, the production domain has centered on a Eurocentric Model where homogeneity is favored.

The study was conducted with three major phases in mind. The first was to bring the reader to an awareness of what it means to build an inclusive community. The second included historical data to confirm the industry's bias practices of exclusion of minorities and women. The third and final phase shows the development and implementation of programming which lends itself to diversifying the performing arts production domain.

Findings concluded an effectiveness of both the content and process of the Performing Arts Production program as a means of providing opportunities for minorities and women toward attaining a successful management careers in performing arts management. Furthermore, this study illustrated a number of programs and opportunities available for minorities and women who wish to embark upon upper level positions within performing arts production. 


\section{TABLE OF CONTENTS}

CHAPTER

PAGE

I. INTRODUCTION 1

II. THE ELLISON MODEL 4

A Description of the Model 5

Implementation of the Model 8

III. LITERATURE REVIEW 14

Statistical Data 15

Effects of Culture and Administration 19

Institutionalized Racism 20

What is the Problem? 21

IV. PROGRAM DEVELOPMENT \& IMPLEMENTATION 24

Ellison Model Techniques: Content-Process-Product 25

FIU Master's Program 30

Disney Experience

V. DISCUSSION 36

$\begin{array}{ll}\text { Summary } & 37\end{array}$

LIST OF REFERENCES $\quad 40$

$\begin{array}{ll}\text { APPENDECIES } & 42\end{array}$ 


\section{INTRODUCTION}

As I embark on this journey I have three major purposes. First, I desire to bring the reader to an awareness of what it means to build an inclusive community. The second is to show the lack of inclusion of minorities and women in upper level positions in the performing arts production industry. The third and final phase shows the development and implementation of programming which lends itself to Inclusive Community Building by way of diversifying the performing arts production arena.

The concept of building is not something new to human society. To build is to form by ordering and uniting materials by gradual means into a composite whole'. Man has been building for thousands of years. In fact archeological findings show that the ancient pyramids were built some time around 2660 B.C.E. (B.C.E. $=$ Before Common Era) ${ }^{2}$. When Thomas Jefferson and his fellows gathered to create a framework for what would later become the United States Constitution, they too were involved in a building process. During the days of the Pharaoh, his family received the bounties associated with the "Pyramid" building work. In Jefferson's day it was those of similar kind who received actual "rights" from the Constitution. From this time on, man has created an environment where certain individuals and groups have benefited most. All too often, these environments have not been inclusive in nature.

\footnotetext{
'Definition as given in Webster's Ninth Collegiate Dictionary.

${ }^{2}$ Old Kingdom: (2664-2181 B.C.E.) This is the time period when the Great Pyramids of Giza were constructed. Some of the greatest artwork of all time was created during this period. See, Tameran and
} 
Culture and language play a great role in how well people are perceived and therefore received by others. Is it possible to have an environment where people are viewed as the components of a salad, where all elements maintain their variety while contributing to that of the whole? If this notion is indeed possible, how can it be achieved? To attain this type of environment it is imperative that society's current views of people of various cultures be broadened to honor and respect each other.

Dr. Deryl G. Hunt, Associate Director of Multicultural Programs and Services at Florida International University (FIU) has developed an interesting model that addresses society's cultural barriers. The model is titled: The Ellison Executive Mentoring and Inclusive Community Building Model $^{3}$. I first learned about the notion of Inclusive Community Building (ICB) during the spring term of 1998 at the Florida State University System/Black Employee's Association conference held at FIU. The conference was centered on "Preparing Black Students for the Millennium: The Role of the Faculty, Staff, Administrator, and Student." I was selected to present a scholarly paper on "The Role of the Educator in Preparing Black Students for the Millennium." During the conference, I attended a lecture given by Distinguished Professor Dr. Lawrence C. Howard ${ }^{4}$. During this session, Dr. Howard addressed the concept of community building with an added twist of inclusivity.

Kemetic Religion.

${ }^{3}$ The Ellison Model is named after Helen Ellison, Associate Vice President, Student Affairs, FIU.

${ }^{4}$ Dr. Lawrence C. Howard is Professor Emeritus, University of Pittsburgh. 
Intrigued with the idea of an inclusive society I sought to gather as much information on the subject matter as I could. At the time I was an undergraduate matriculating at Florida A\&M University. Upon graduation, I sought to attend FIU. At the time, I was unaware that I too would become a vital tool in this building work. To receive more information on this inclusive community building effort I was paired up with Dr. Hunt as an assistant in the office of Multicultural Programs and Services at FIU.

Over the past fifteen months, I have been actively involved with Dr. Deryl G. Hunt as a learner and dispenser of knowledge as it relates to the ICB principles. Inclusive Community Building, in theory and practice is a three-step process of moving from diversity, to unity, toward the end of building a true community. It invites the participation of all groups to accomplish a particular goal. In this case, the goal is to build community.

The first step of ICB is Diversity. Diversity is a topic many people discuss nowadays when addressing current issues on race relations. Diversity is often looked upon as difference. An acknowledgment of our differences doesn't create a better society; it only increases the number of barriers drawn between cultures. ICB principles view diversity as variety where we all possess similarities that bind us together. The second step is Unity. Unity is about acquiring a vision that is shared among the communitybuilding participants. Once there is an established common bond, we can then move on to community. Community, in this case, is viewed as fellowship. 
CHAPTER 2

THE ELLISON MODEL 


\section{THE ELLISON MODEL}

\section{Sharing Personal \& Professional Knowledge}

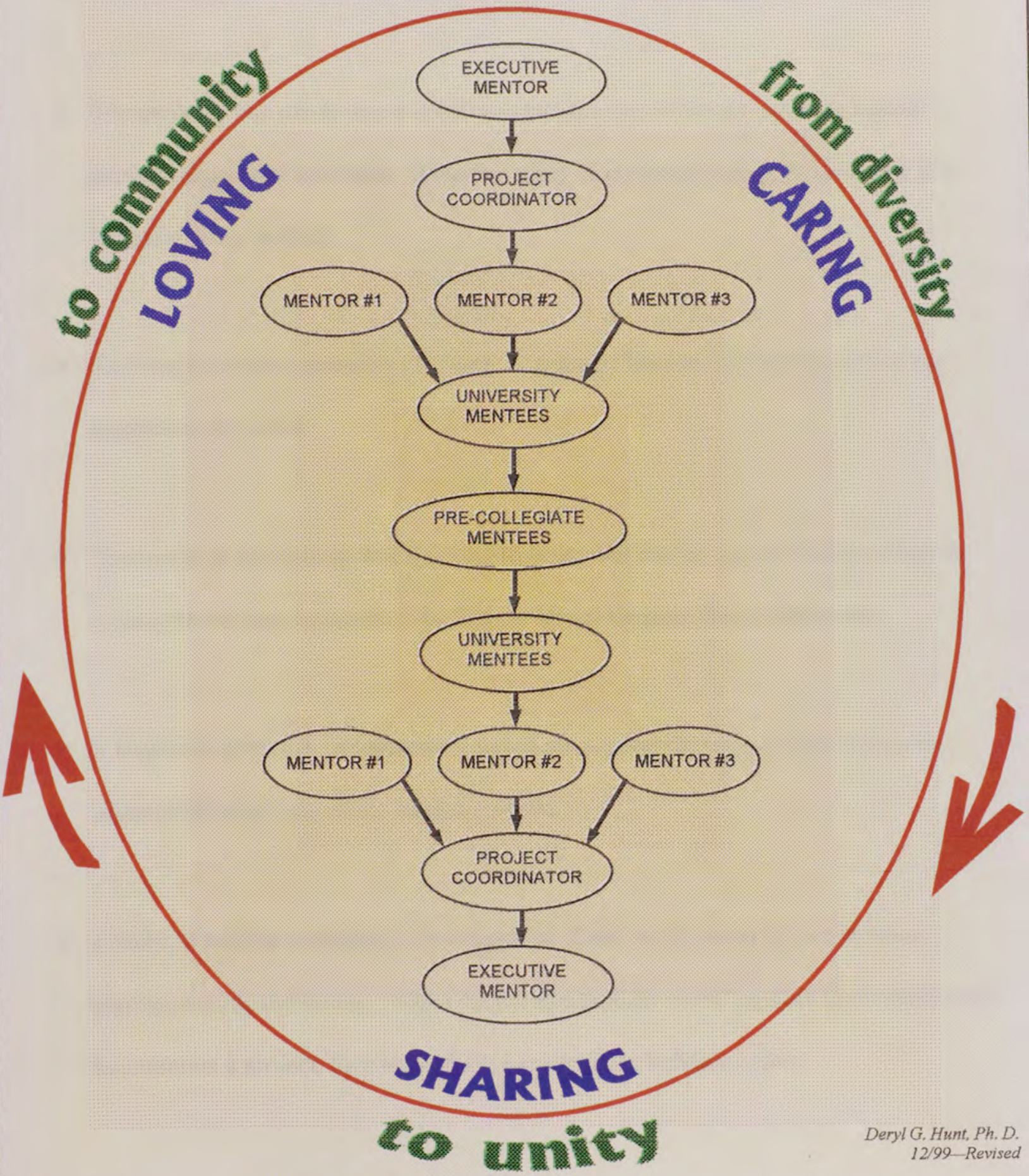

Giving Feedback Respecting Right Ways Honoring the Honorable 


\section{A Description of The Model}

The Ellison Executive Mentoring and Inclusive Community Building Model is a holistic, economic and efficient method of delivering services.

The model is holistic in that it involves a community of people acting in concert to perform organizational tasks. It teaches unity of purpose, sharing of ideas and it is inclusive in its outlook.

The model stresses economy of scales. It expands limited resources by involving partners in the work.

The model is efficient in that it is simple to use and can be used by a large range of organizations (see Appendix I for Ellison Model Organizational Structure).

It is product oriented. Evaluation is based on whether the project objectives are accomplished by way of the team approach.

Finally, it teaches community development. Community development is about caring, sharing and loving. When people successfully work together in the right spirit to complete a project, they show forth a community building effort. 
The Model is an alternative method of delivering services. It relates to the mentee as learner and dispenser of acquired knowledge. This model deviates from the traditional mentor/mentee relationship by taking the position that the mentee has much to share while in his/her course of study.

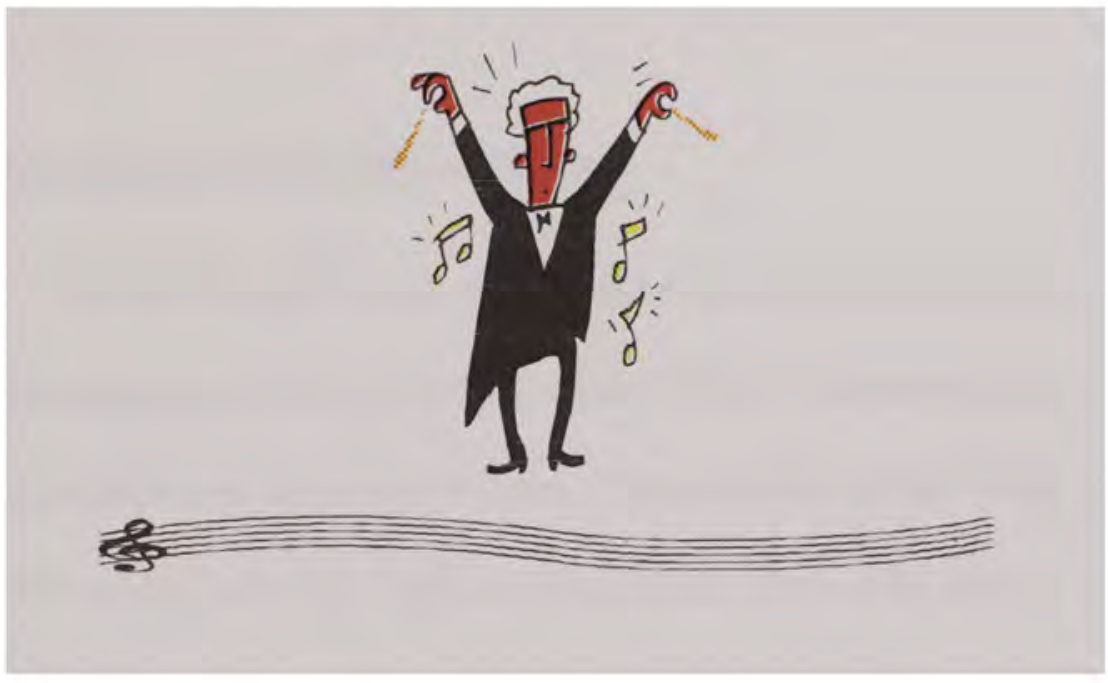

Mentors are seen as "directors." A director is one who guides. The director of a philharmonic orchestra is key to each player performing in concert with all others. He or she is looked upon as a leader of the group. In much the same way, mentors guide mentees. The Producer or Director, who spends extra hours with a Production Associate (PA) after a show or rehearsals to encourage him in further endeavors, serves as a mentor or director. The PA is able to successfully complete his project because of the expert knowledge of the director.

In a production, the Producer is not the only player. The success of his production lies within the quality individuals in his production ensemble. The Stage Manager, 
Audio Technician, Lighting Designer, Director, Casting Director, etc are allowed to play. When all members of the team act in perfect harmony, a sweet melody is heard in the production camp. In a word, the production team is a community of performers. When each member treats other members with respect and honor, the community takes on an inclusive character.

\section{Implementation of The Ellison Model}

The MPAS staff has used the Ellison Model to nurture a relationship with the Nondenominational Student Support Club of FIU. This nurturing has included nearly a dozen projects over the past five years. These projects include Cultural Fest '94, Understanding Culturally Different People, The Letter of the Law vs. The Spirit of the Law, When Two Cultures Meet, Action Not Affirmed, The Glass of Diversity, and an endowment for Bahamian students to attend FIU.

The primary goal of Cultural Fest ' 94 was to encourage students from different countries and students from this country to work together on a community program that celebrates the diversity of the campus and the South Florida area. The program included providing opportunities for the international students to share their way of life through exhibits about their cultures, customs, food and dress.

Understanding Culturally Different People, focuses on four training modules: Understanding Culturally Different People, Culture and Administration, The Culture of 
the Spirit, and Building Community. The modules were specifically designed to provide opportunity for individuals and organizations in the private and public sectors to address diversity as it leads to unity in order to build the inclusive community.

The Letter of the Law vs. The Spirit of the Law is a compelling play, which addresses the concept of the strict and literal interpretation of laws versus the intended meaning behind them. The author uses an incident in a classroom to bring to the forefront the issue of interpretation of laws.

When Two Cultures Meet depicts the meeting of people of different cultures. The play examines the relationship that develops between three pairs of people where one party moves from one culture to another, exhibiting unity.

Action Not Affirmed ${ }^{5}$ is a play based around the political campaign of 1912: Woodrow Wilson's campaign for the administration of justice (or so it seemed). Negro leaders, such as W.E.B. DuBois, endorsed Wilson and called for a major shift from the traditional loyalty that had been given to the party associated with Abraham Lincoln, Emancipation, and Congressional Reconstruction. The traditional loyalty was to benefit the condition of whites and not blacks. Although Wilson was an accepted scholar and past president of Princeton University, DuBois lectured him on what freedom should

\footnotetext{
${ }^{5}$ Action Not Affirmed is taken from an unpublished manuscript by Lawrence Howard and Deryl Hunt titled, Praxis: A Cultural Approach to the Study of Public Affairs.
} 
mean. DuBois was also a scholar and a spokesman for Blacks' rights. The only differences between the two were skin color and their perspectives on administration. I should add that the three plays and original musical scores were written by Dr. Deryl G. Hunt as part of the training of the NSSC in developing the Alternative Student Services Delivery System. I must take this time to applaud Dr. Hunt for the use of the arts in incorporating innovative programming.

I first experienced "Action Not Affirmed" at the Spring 1998 BEA/Florida SUS Conference on "Preparing Black Students for the Millennium..." After the performance his fellow, Dr. Lawrence C. Howard inquired as to my feelings on what I had seen and heard. I went home and gave his inquiry much thought. I then wrote him a response that read:

Dr. Howard, In an effort to understand the gravity of music in the play "Action Not Affirmed", it is imperative that one have knowledge of the ways an artist views various art forms. The two most widely accepted views are Absolutism and Referentialism ${ }^{6}$. The Absolutist sees art as its own beginning and end. He subscribes to the belief that the meaning and nature of art exists in art itself. Any attempt to give a verbal explanation decreases the value of art in its true form.

The Referentialist believes that something other than art contributes to its conception. An artist's idea derives from ones surroundings, thus giving it a sense of meaning before the work began. Because this play is the result of ones interpretation of a book, it is necessary to take a referentialistic approach to the aesthetic impact of the work.

In the presence of music, one hears melody and feels rhythm. This fosters an arousal of one's cognitive and psychomotor skills. In "Action Not Affirmed," the hearing and feeling of music was used to induce the entire body into the learning process. The

\footnotetext{
${ }^{6}$ Theories as discussed in Bennett Reimer's, A Philosophy of Music Education.
} 
choreographed dancing scene afforded one the opportunity to see what was being felt and heard. "Our eyes send 430 times as many messages to the brain as do our ears?." Inviting the eyes to join in on the auditory and kinesthetic modes resulted in the ability to process information at an extremely high level.

Near the end of the play, the lead singer asked the audience to join in singing. This wise tactic incorporates the "hands-on" approach to learning. The result was the incorporation of auditory, kinesthetic, visual, and tactile modes of learning. This is probably one of the few instances where all four modes are combined to aid learning, thus stressing the importance of utilizing the arts as a tool to enhance education.

\section{Kawachi Clemons}

$04 / 17 / 98$

The Glass of Diversity ${ }^{8}$ is a team building training session that utilizes the principles of The Ellison Model to encourage unity among staff members. It calls attention to the cleaver ways people use "buzzwords" to hide nefarious intents even as it points to the need to see diversity as a two-edged sword either unifying or dividing. In addition to a review of The Ellison Model, it unfolds in four phases: 1) GOMA, 2) A one act play, "The Glass of Diversity", 3) "Building Community" and 4) "Building the Inclusive Community: a visual demonstration". The first song "GOMA" addresses the project's Goal, Objective, Method, and Attitude. Our goal is Community while the objective is Unity. The method is Respect and out attitude or disposition of heart in approaching the work is one of Honor. The song is an icebreaker, setting the tone for the work that follows. Agreement takes place by engaging audience participation. By

\footnotetext{
${ }^{7}$ Arthur S. Seiderman and Steven E, Marcus, 20/20 Is Not Enough.

${ }^{8}$ The Glass of Diversity is the result of collaboration between Dr. Deryl G. Hunt (mentor) and Kawachi Clemons (mentee). As such, it is a demonstration of The Ellison Model's principles where the focus is on developing the more excellent student.
} 
chanting, clapping, and singing along, the group demonstrates a sense of unity that leads to Community outlook. The play, "The Glass of Diversity" is an entertaining approach that educates. Taken from a classroom setting the audience begins to see how the professor relates diversity in everyday life. The approach here is to allow one to see Diversity as a glass that can give life or destroy life. The second song, "Building Community" mirrors the message that was brought forth in the play. It sets the themes of diversity, unity, and community to a catchy little tune that is easily remembered. This approach is similar to that of a young child learning his/her alphabet by singing the Alphabet song. For those not easily moved by music or theater, the final phase offers the message of community building in a visual diagram. In this diagram, one is able to visualize the message of moving from diversity to unity to community. When one looks at the project as a whole, it is easily seen that it teaches by way of entertaining. George Koller, Senior Show Director, Epcot Entertainment discusses his thoughts on the song "Building Community" as a means of fostering community:

As a writer and director, there is not a question in my mind regarding the POWER and impact of music in teaching, influencing, and moving an audience. (Just consider the impact of "we are the world" or the influence of advertising jingles and slogans -- music and lyrics can be a road to one-mindedness and unity.) It would not be possible for me to enumerate the shows in which I have used theme-based songs as opening numbers, closing numbers, and music bases for visual presentations. Within the context of a production, in which an audience has allowed itself to become emotionally involved, there is the potential to elicit an emotional response, as well as the opportunity to "sell" a meaningful message to which the audience is open (overtly or covertly). The lyrics which Kawachi Clemons shared with me illustrate this "power." Built into his words are implications of communication, trust, and loyalty. Then, the refrain, "we are building community," makes it all gel in the mind of the listener. Add to this the impact of the music, the performer(s), the venue, and the context -- and you could have a win-win situation. 
Using the NSSC as our test group, we are able to see the following:

- Students viewed as both learners and dispensers of knowledge.

- Holistic approach to learning (educating the whole student: spiritually, intellectually, physically)

- Mentoring (3 tol mentor/mentee ratio with an executive mentor serving as project head)

- Team Approach (accomplish tasks as a team)

- A product oriented program

- Evaluation based on accomplishment of objective via a team effort

- Community in its outlook (inclusive-all members are viewed as one unit or cell working to accomplish a single goal)

- Symbiotic student/university relationship (students gain knowledge and in return share knowledge with others by way of volunteer efforts)

- Supplemental instruction (skills based learning: reading, writing, and computing)

Again showing the growth of the student centered program, the NSSC has developed a Song and Dance Troupe. The song and dance troupe, utilizing FIU students, and pre-collegiate students under the direction of the MPAS staff, participated in a benefit concert to raise funds for Bahamian students to attend FIU. The benefit raised $\$ 5,000$ towards the cause. In my research, I found that only one of the fifteen students involved in the Bahamian project was of Bahamian descent. This project shows the degree of mutual respect and concern the students have developed for those of other cultures. 
CHAPTER 3

\section{LITERATURE REVIEW}




\section{Statistical Data}

During the 1970s, there was much discussion of whites profiting from the production of black films. Renee Ward, who at the time was an investigative reporter for The Chicago Reporter conducted a comprehensive investigation of the impact of Black films in the Chicago Loop* area. A "black film," as defined in the article is one in which the cast or theme is predominantly black, and who's targeted audience is of a black majority. The findings of this 20 -month study include the following:

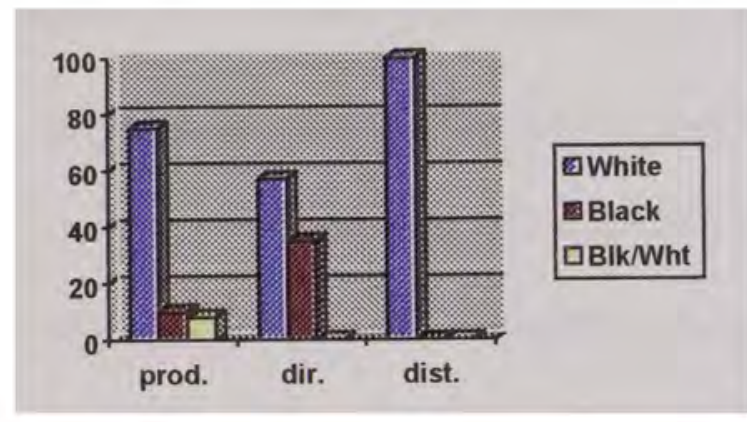

* Includes the Chicago, Loop, Oriental, Roosevelt, State Lake, Todd, United Artists, and Woods theatres. A total of 52 black films were shown during the study period.

Of the 52 black-oriented films shown at the eight theaters during the study period, 39 films were produced by whites, five by blacks, and four co-produced by black/white teams. In the area of direction, 30 were by whites and 18 by blacks. None of the films were distributed by blacks. The 52 black-oriented films grossed $\$ 8.2$ million ( $41 \%$ ) of the total box office receipts of $\$ 19.8$ million taken from the Loop area. It was also found that many of the black films produced appeared to be rather profitable over their run.

In particular, the movie "Scream Blacula Scream" grossed \$141,500 in four weeks. 
By comparison, the "Three Musketeers" grossed $\$ 101,300$ over a seven-week span.

Twenty-eight years later the numbers are still tremendously low. In 1998 the Directors Guild of America (DGA) released their annual employment report. The shocking report shows a continued lack of inclusion in hiring practices of minorities and women in film and tape. The report shows the total number of worked days by women and minorities in 1998. (In addition, it tracks the percentage of hiring statistics since1983.) The results from the report are as follows:

- DGA women directors worked $10.2 \%$ of the total days worked by Guild directors during 1998; down from $10.7 \%$ in 1997 . This is the lowest employment level for DGA women directors since 1990, and marks the third consecutive year that employment levels for women directors have declined.

- DGA minority directors worked $8.4 \%$ of total days worked by Guild directors in 1998; down from $8.6 \%$ in 1997. Employment of African-American directors was static at $4.4 \%$, while Latino directors fell to $2.3 \%$ from $3.1 \%$.

- DGA women tape directors went from $19.5 \%$ in 1997 to $16.3 \%$ in 1998 .

- DGA minority tape directors dropped from $14.1 \%$ in 1997 to $10.8 \%$ in 1998.

African-American directors fell from $6.9 \%$ to $5.2 \%$; while Latino directors dropped from $5.1 \%$ to $3.9 \%$. 
- DGA women film directors (theatrical and non-theatrical) went from $7.1 \%$ in 1997 to 8.5\% in 1998.

- DGA minority film directors (theatrical and non-theatrical) went from $6.4 \%$ in 1997 to $7.7 \%$ in 1998 .

Although there were gains in the film category the resulting overall statistics show a decline in numbers.

Minority directors are not the only ones feeling the brunt of the lack of inclusion in Hollywood. Minority actors feel the day-to-day stress of not being considered for leading roles. Black Hollywood actors are often cast as street thugs, athletes, drug dealers, and drug users. "The fact is despite figures showing that women account for a huge share of box office receipts, and that Blacks, though only $13 \%$ of the population, represent an estimated $30 \%$ of moviegoers, studios have never been interested in portraying Black men as fully realized sexual beings." To date, there have been few Black actors to achieve success on the silver screen. Even when cast, these actors are often seen as hard knocking detectives, reporters, and athletes; i.e. Wesley Snipes in Murder at 1600, Denzel Washington in The Pelican Brief, and Cuba Gooding, Jr. in Jerry Maguire. Can a "brother" not portray the leading romantic roles often held by the Robert Redfords of Hollywood? Molefi Kete Asante, Ph. D., professor of Africology at Temple University explains: "The ideas of tenderness, communication, and the pursuit of love

\footnotetext{
9 "Where is the Love?" A featured article written in February 2000 issue of Essence magazine.
} 
are considered foreign to the African-American experience by White producers and directors. There is a geography of fear, and it begins at the core level of ideas in the society. And those who are involved in making movies have not said, 'Hey, wait a minute. There is a problem here.' They don't even see it. ${ }^{10 "}$ There is no doubt in my mind that Blacks "have what it takes" to sell the leading romantic role. Billy Dee Williams proved this to be true years ago in Lady Sings the Blues.

Even when afforded the opportunity, non-white actors and directors lack recognition for their skills and contributions to the film and television industry. In 1998, a Los Angeles newspaper reported the concerns of blacks being shut out of top Oscar nominations.

\section{Monday February 23, 1998}

Los Angeles (AP) - When it comes to honoring black actors, Academy Award voters have a perfect record: perfectly awful. The black shutout for top Oscars is indicative of a deeper Hollywood problem. The film business is run by whites, and creative decisions reflect that homogeneity. (The Academy's membership is an estimated $95 \%$ white.) "The absence of minority representation in the Oscars is really about the absence of any concerted, sustained representation of minorities on screen," says Todd Boyd, a Professor of Critical Studies in the film school at the University of Southern California. Bringing minorities - Black, Asian, Hispanic or any other group - to the screen involves change. And change means danger. One white Oscar-nominated filmmaker says a studio recently killed a planned civil rights film because the studio believed the movie was "too black." Spike Lee is quoted by saying, "The Academy only likes certain kinds of black performances: Gooding's athlete or Morgan Freeman's chauffeur in Driving Miss Daisy."

\footnotetext{
${ }^{10}$ Essence magazine, February 2000 issue.
} 
What is the underlying explanation for these outcomes? In lieu of all plausible explanations, one could not rule out the effects of culture and administration, and the practice of institutionalized racism.

\section{The Effects of Culture and Administration}

To a great extent, "culture" has played a pivotal role in the lack of inclusion of minorities and women desiring to climb the ladder of success in the performing arts production domain. Culture, in its simplest form, is "a way of life." This way of life includes food, clothing, geographic location, and language, to name a few.

George Peter Murdock on Culture:

Culture is the product of learning rather than heredity. The cultures of the world are systems of collective habits. Hunger, sex, fear, and other basic drives as well as acquired motivations, impel human beings to act. Actions encounter either success or failure. With failure... an action tends to be replaced by other behavior, and its probability of recurring under similar conditions is diminished. Success, on the other hand, increases the tendency of responses to occur when the same drive is again aroused in a like situation. With repeated success, responses are established as habits, and are progressively adapted to the situations in which they are appropriate ${ }^{11}$.

The culture of performing arts administration, in many ways has predicated on the myth and beliefs of the culture of days-of-old where non-whites were considered as second-class citizens. In the arts, a select group is allowed the opportunity to make the

\footnotetext{
$"$ Harry L. Shapiro, Man, Culture, and Society.
} 
important decisions that control the destiny of the entertainment field. These individuals, usually white males, control all of the distribution for music, film, television, and live production. Through distribution, these select few maintain the ability to manipulate the industry.

\section{Institutionalized Racism}

Institutionalized racism in theory and practice is a system of exclusiveness that has shut the doors on many individuals who have the talent and desire to produce and direct in the performing arts production arena. For years, racism $^{12}$ has been a way of life for American culture. Throughout these years "thousands of overtly racist laws, social institutions, behavioral patterns, living conditions, distributions of political power, figures and forms of speech, cultural view points and habits, and even thought patterns continually forced colored ${ }^{13}$ Americans into positions of inferiority and subordination." The effects of racism are still prevalent today. Racism, in terms of culture, is seen as "ideologies and practices transmitted through mundane intergenerational socialization processes which give taken-for-granted credence to the centrality of race in defining self, others; making critical and routine life choices such as residence and mate selection; and determining "natural" power, authority, and prestige rights in a society ${ }^{14}$." More than often non-colored individuals perpetuate principles of institutional racism.

\footnotetext{
${ }^{12}$ Racism as defined here is directly related to ones ability to act on prejudices based on power, Sharon $D$. Wright, "Race and Civil Rights in the Contemporary Era."

${ }^{13}$ Colored individuals are defined as Black, Asian, Hispanic, Mexican, and Native Americans.

${ }^{14}$ For more on this viewpoint see John H. Stanfield, "Theoretical and ideological Barriers to the Study g.
} 
In some cases, people of color believe in the premise of racism and often settle for low menial standards.

\section{What is the problem?}

The country we call America is a place where anyone can achieve limitless opportunities. The difference between the races is a question of resources. All too often minorities and women lack the resources to acquire a successful career in the performing arts production arena. Let me take for example three directors who all possess a certain amount of funding for their individual projects. Director $\mathrm{A}$ has $\$ 3,000$, director $\mathrm{B}$ has $\$ 2,000$, and director $\mathrm{C}$ has $\$ 1,000$. Let us assume that these directors approach the same producer for additional funding for various projects. The producer has $\$ 6,000$ to distribute. How should the funds be disbursed?

Your answer. Give specific reasoning for your choice in distribution.

If you chose to give each director $\$ 2,000$, you have done what society has done for minorities and women all too long. You have essentially done nothing to change the 
current situation. Simply put, those who have, just merely have more. Moreover, more than often certain individuals still maintain a marginal gap in the amount of resources offered to those not in their homogenous group. Conversely, if you chose to look deeper into the problem you would have seen a more positive solution. Another solution is to give directors $\mathrm{A}, \mathrm{B}$, and $\mathrm{C} \$ 1,000, \$ 2,000$, and $\$ 3,000$ respectively. This solution attempts to even out the playing field by affording each director the opportunity to have access to the same resources, $\$ 4,000$.

In an address at Duke University, Julian Bond shared his thoughts on race relations by stating: "Affirmative action really isn't about preferential treatment for blacks... It's about removing preferential treatment whites have received throughout history." This statement from Bond reaffirms what minorities and women are seeking in today's quest for equality. These individuals and groups are requesting the occasion to be granted an all-access pass toward opportunities that will yield favorable outcomes. In the area of performing arts production the favorable outcomes include but are not limited to positions as producers, directors, writers, and actors in leading roles.

One reason for the lack of inclusion is that up to this point there have been few programs implemented to facilitate the use of the mentor/mentee relationship as discussed in the Ellison Model. The Hispanic Congressional Caucus Entertainment Task Force has prescribed a remedy to existing conditions of exclusion. Three areas of concentration should be followed in order to discover opportunities available in the entertainment 
industry: 1) Opportunities in Internships, Fellowship programs, and Page programs, 2) Mentoring for Hispanics (minorities) who wish to enter the industry, and 3) Development of an employment pool.

To offer an example of a corporate 'buy in' to increase the numbers of those groups underrepresented in upper level production positions, I will briefly discuss a new graduate program instituted at FIU. The program is a Master of Music in Performing Arts Production ${ }^{15}$.

${ }^{15}$ Additional information on this program may be obtained through the FIU School of Music. Karen Fuller, Program Director, email: fullerk@fiu.edu 
CHAPTER 4

PROGRAM DEVELOPMENT 


\section{Ellison Model Techniques: Content-Process-Product}

As previously stated, the Ellison Model is product oriented. The product serves as proof the program objectives are being met. In terms of educational programming there must be a systematic approach toward achieving the desired product of increasing the numbers of underrepresented groups as producers, directors, and managers within the production industry. To facilitate this case study, The Ellison Model Technique of Content-Process-Product will be employed.

Content refers to a particular subject area or component of subject matter.

Supplemental instruction must take place to provide the student with more than adequate information of all aspects of the production process. To achieve success the content must be administered in a way that is clearly defined.

Once the student has acquired all necessary information, the second phase of process must be encountered. Here the student utilizes the information presented in the content phase to show he/she has attained the management skills needed to perform in any given production situation (knowledge).

Mastery of content is showcased in the process phase which in turn results in a favorable product. If the desired product is not accomplished the student (mentee) and 
instructor (mentor) must revisit and analyze the content and process phases to see where a break down occurred.

\section{FIU Master's Program}

The Master of Music degree program in Performing Arts Production is geared toward producing qualified individuals to pursue successful management careers in the entertainment industry. The importance for using this program is that it is in collaboration with Walt Disney Entertainment. Choosing FIU as the site for this program is significant because of its history of possessing a multicultural student population. The following graph shows the program's student ethnic break down (fall 1999 semester): Black - three students (20\%), White - seven students (47\%), Hispanic - three students (20\%), and Asian - two students $(13 \%)$.

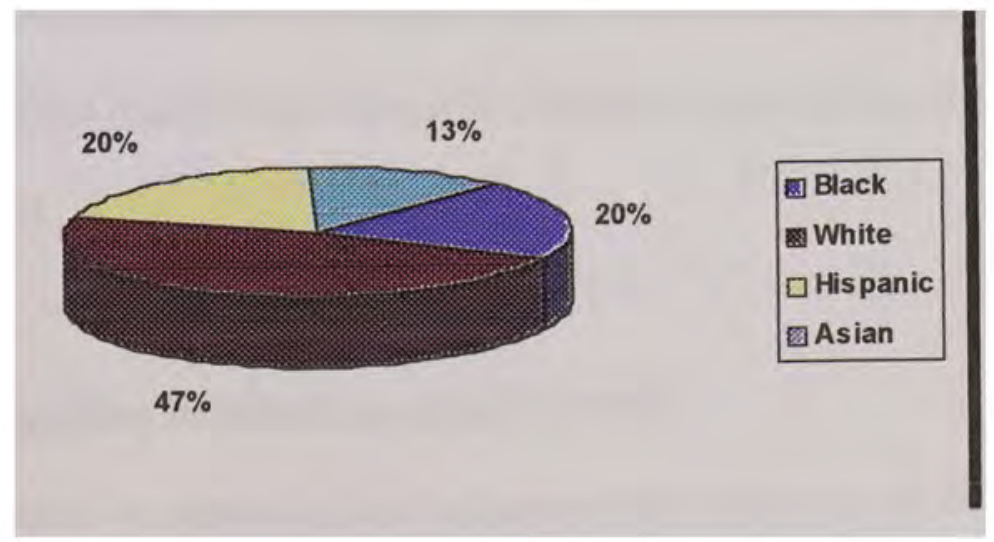


Students on the master's track engage in three semesters of tactile learning (content). The three semesters include:

\section{Performing Arts Production I ( 2 credits)}

Course focuses on the various aspects of performing arts production. Students attend performances of every possible genre of performing arts and critique the production and the venue. Course prepares student for a successful performing arts management career.

\section{Live Music Operations I ( 2 credits)}

How promoters and producers project a profit margin and the ability to oversee a profit; considering overhead, scheduling, accommodations, concessions, sound and light. Covers various aspects of promoting, supporting and managing live performance venues.

\section{Sound Reinforcement ( 2 credits)}

Exploration of live music on location, dealing with commonly encountered acoustical problems and how to overcome them. Course delves into the needs of various ensembles in actual practice and exposes the student to state of the art sound equipment and how to use it.

\section{Expanding Artistic Expression (2 credits)}

Focuses on expanding the horizons of the artistic vision of the student. Accomplished through a series of projects. 
Student is assigned to work in the production of a series of individual concert productions. The productions are varied and provide students the opportunity to put in practice work learned in the classroom.

\section{Live Music Operations II ( 3 credits)}

Continuation of Live Music Operations I. Emphasis on promoters, producers and managers ability to project a profit margin including overhead, scheduling, accommodations, concessions, sound and light. An on campus production is required as the final project.

Performance Lighting ( 2 credits)

An introduction to lighting for entertainment arts performances such as those presented at theme parks, concerts, and outdoor performances.

\section{Computer Literacy for Performing Arts Production ( 2 credits)}

Designed to familiarize students with the fundamentals of computer theory and operation using the most accepted performing arts computer platforms. Word processing, spreadsheets, graphics and database applications using existing performance arts production based software. 
Music Production Lab II (1 credit)

A continuation of Music Production Lab I.

\section{Advanced Business of Music ( 3 credits)}

Topics include strategic planning, employee development, and decision making. Also includes a study of publishing, collection agencies, creative unions, and contracts with composers and producers.

\section{Performing Arts Technology (2credits)}

Develops informed performing arts management level professionals in the direct applications of structural, mechanical, electrical and electronic technologies.

\section{Music Production Lab III (1 credit)}

A continuation of Music Production Lab II.

\section{Thesis ( 3 credits)}

The final requirement for graduation. An analytical/research paper is based on this final project.

In addition to studying at the university, students attend monthly workshops on Walt Disney property in Orlando, FL. These workshops offer first hand experience on everything from show development life cycle to post mortem analysis. Once a student has successfully completed three semesters of study they are then paired up to intern with 
a director within the Walt Disney Company (process). Current intern directors' positions vary from Vice President of Entertainment to Manager of Creative Costuming.

The internship provides an inside look at production through the eyes of Walt Disney Entertainment. This tenure also provides the opportunity to meet and network with some of the industry's leading creative individuals. In this business it's about talent and connections. The connections acquired through this and other internship type programs ${ }^{16}$ furnish individuals with outlets to express those talents.

\section{Walt Disney World Internship Experience}

The following is an account of my experience as an intern with Epcot Entertainment ${ }^{17}$ as well as events that led up to the internship process.

For the past few months I have been serving as an intern Entertainment Manager at the Walt Disney World Resort, Epcot Special Events division. Before receiving an internship appointment I had to submit a resume showing my past production experience. While at FIU I had the opportunity to develop a production resume by getting involved with a number of high profile production engagements. During the Spring 1999 semester members of the Performing Arts Production program were hired by Radio City Entertainment to serve as Production Assistants for Super Bowl XXXIII Halftime Show.

\footnotetext{
${ }^{16}$ Additional programs are listed in Appendix 4

${ }^{17}$ The detailed journal account is listed in Appendix 5
} 
This was my first experience being on the non-performing side of a high profile production. All my past experiences were as a musician, either performing live or in studio situations. The Super Bowl provided the opportunity to meet and network with some of the industry's top professionals. During the Super Bowl I was assigned to work with Director, Paul Miller, and Associate Directors Christine Clark-Bradley and Sharon Taylor. This was the opportunity of a lifetime. While working with them I later found out that they were among the top directors in television. After many days of open discussion I asked Sharon, "How can I achieve their level of success as a director or producer?" Her response, "You have to become more involved with the big events." Taking this into consideration I asked, "Where can I sign up!" I later found out that in the industry it's all about who you know. There are no applications for becoming a big name producer or director. You have to some how get your foot in the door to show that you're interested in becoming a success. I made it my business to acquire all the information I could from Paul, Christine, and Sharon. Before the end of the Super Bowl assignment, I was asked if I would be interested in joining them to work on the Grammy's. Considering it was only a few weeks away and I had already taken a month off from school, I respectfully declined. They then offered me the opportunity to join their team as a Production Associate for the $73^{\text {rd }}$ Annual Academy Awards. This one I accepted. The PAP program put me in touch with individuals that would assist me by providing ample opportunities to build my production portfolio. As a result I was able to include these productions as part of my professional experiences. 
Once the resume was submitted I received an interview session with Laurie Speights, GM, Epcot Entertainment. She was impressed to see how active I had been in performing additional events that were not in the program's curriculum. In addition to Super Bowl XXXIII and the Academy Awards I attained experience by assisting in the Office of Multicultural Programs and Services (MPAS) at FIU. While at MPAS, I coordinated a number of events including Unity Day: A Student Life Activity. It was this event that provided the most experience at managing large events. I was required to develop a budget, acquire talent, audio services, and tents to house the event. Laurie found this to be extremely impressive. After the interview she invited me to work with her special events and conventions team during my internship.

Once I arrived on Disney property, I was provided an overview of Entertainment's operating procedures. I spent the first few weeks shadowing Entertainment Managers. I found that many of their methods of operation were similar to what I had been engaged in while working and studying at the university. To diversify my experience I asked George Koller, Senior Show Director, Epcot Entertainment, if I could shadow him a while to experience Disney's creative development process. He agreed. The project he was currently embarking on was to create a finale show for the FIRST 2000 Robotics Competition. This is one of Epcot's premiere events. I accompanied George and Tom Ciupak, Entertainment Manager one afternoon to view the possibilities of incorporating lasers into the finale show. During the laser demonstration I began to sketch out many ideas that were popping in my head. After the demonstration we had a brainstorming 
meeting over lunch. I was then asked what I thought of the lasers. I shared my ideas with them. Interestingly enough, they found some of them to be creatively insightful. I was then asked to continue with them through the show developmental life cycle. I found myself sitting in creative meetings with directors, producers, effects design specialists, Disney i.d.e.a.s., and many others. I was able to experience first hand the fruition of many ideas to final product.

One day, a fellow manager asked if I would ease his load by covering an event. I agreed. To date I had only shadowed other managers. This would be my first solo event. Because of the success of this event the staff assigned me additional responsibility of managing more events on a solo basis.

After each event it is customary to submit a written event recap. The recap is used to provide the opportunity for input from others on creating better events in the future. Once the recap is submitted the account manager usually responds. In my case the account manager and client was extremely impressed with my professionalism and attitude (At this point very few people knew I was an intern) ${ }^{18}$.

Near the end of my stay at Disney, George Kalogridis, one of the company's vice presidents requested to see me. He too didn't know I was an intern, he just knew that every time he looked around he saw me managing events. Laurie then shared that I

${ }^{18}$ Entertainment recap with actual account manager's response is listed in Appendix 6. 
was on an internship program. George, like many others were impressed to see how easily I transitioned as a key player on the entertainment team. It is no mystery to me how my success came about. It was through the knowledge obtained in the Performing Arts Production program combined with extracurricular activities and university programming that I was able to adapt to a variety of situations while on internship. After the internship I was presented with opportunities to possibly stay with Disney. Although Disney has provided me with an increased amount of knowledge of the production industry, I felt it wasn't the right time. As a mentor, Dr. Hunt has shared personal and professional knowledge that has aided in my overall development. I have decided to return to MPAS to give back to the university community. I believe that my increased level of managing events will truly be an asset to FIU. Once I successfully completed the internship I was given CT(Casual Temporary) status, for possible future work within the Walt Disney World Company. I hope to one-day reunite with the Epcot entertainment team to create more Disney memories.

At the end of the internship George Koller shared a few personal and professional comments regarding the Performing Arts Production program as well as my Disney experience:

Looking at the Walt Disney Entertainment Management profile, one notes that the large majority have "come up through the ranks" - having worked as performers, stage managers, production assistants, or technicians. Undoubtedly, one develops "promotion clout" after working with, and getting to know the staff, company traditions, and day to day "modus operandi." Especially in the case of interns or apprentices, the opportunity is invaluable for the Company to SHAPE an employee as he/she is learning and growing within the system. It's as if the entire training process takes place prior to even being hired. And, in the case of Mr. Clemons' experience at Walt Disney World, he was able to observe shows, experience the backstage venues, attend meetings, and "shadow" many 
diverse employment roles - salaried, hourly, administrative, and creative. He seemed to like us - we liked him - the potential is there for hiring.

Chip Koch, Manager, Entertainment Operations, Epcot also shared a few comments about the Disney internship process:

In a search for qualified candidates to fill leadership positions within our company, so many of the qualities we look for are the qualities that are learned and exposed during a practical working experience. Whether it's personnel, timelines, maintaining quality or measuring success, the value of having "done it" speaks much louder than a classroom experience alone. This does not imply that one goes without the other, nor that one is of greater value than the other, through an individuals own efforts (unique to each person) the combination of a classroom experience and a practical experience like your internship, will have a much greater reward than one of those alone. Specifically here at Disney, I believe the internship enhances the potential of an individual and exposes them to a medium of the Performance Arts that few others know well.

All of us here at Epcot were impacted by your participation on our team, and can't help but be moved by your conviction and quest for "something even better!" I believe that through your expression, others will feel the same impact. Undoubtedly, your commitment to quality, creativity, community and unity are characteristics that you are well respected for... and will be remembered for. 


\section{CHAPTER 5}

\section{DISCUSSION}




\section{Summary}

"Not by the color of our skin, but by the content of our character..." This was the dream of Dr. Martin Luther King, Jr. As we begin this next millennium, there is a need for mankind to build a community where character content is the primary focus. The community I envision is one that is inclusive in nature. Its attitude is one of honor. Honor is given to the father, mother, and those in authority. True honor softens the heart and fosters a mutual respect for all from within. The inhabitants of this inclusive community are a forgiving people. To forgive is to understand that people make mistakes. This understanding places the focus on the deed, not the doer. Ideas and resources within this community are shared. No one element dominates; people work together in a common good to foster mutual welfare and friendship. People are honest in their dealings and acts of civility are common practice.

The inclusive community possesses a passion that is second to none. Those within this community are willing to sacrifice for the good of others, ever empathizing with the lowly in society. Its desire to improve the human condition is evident in committing unselfish acts of love toward those in need. One for all and all for one. Unity is the slice of life. People are united in the single cause of building loving character in the hearts of man, woman, boy and girl.

The revealed wisdom of this inclusive community is a vision of hope. The focus is on the attitude of the heart. When one's heart is inclined toward positive initiatives, 
life is given to the community. Life springs forth with a vigor that invites others to a "circle of friendship." It is in the circle where people have a true understanding of culturally different people. Because of its compassionate nature it teaches all how to secure riches and bounties. Those who are together stand, those who are divided fall. In a word, this community is likened to a choir. The choir is made up of a variety of people, uniting in a single cause to build community. All people have a voice in this community. Each voice has a part to sing. The variety of socioeconomic levels adds to the rich timbre of the ensemble. The result is truly harmonious.

In analyzing the Performing Arts Production program by way of the Ellison Model Technique: Content-Process-Product, I have come to the conclusion that the program has provided a degree of success by creating opportunities for professional development of minorities and women. Through the development and implementation of the PAP-Disney internship, the Hispanic Congressional Caucus Entertainment Task Force's findings are also addressed. One can only hope that the program continues its efforts of producing qualified individuals to pursue successful management careers in the production industry. The product presented only represents that of one participants' experience. I have the desire to revisit this study in a few years by interviewing additional interns from the program toward the end of observing and documenting the long term effects of the Performing Arts Production program on the production industry as a whole. Until then, we must all continue to strive to build an inclusive performing arts community. 


\section{LIST OF REFERENCES}

Blacks shut out of top Oscar nominations, 1998. Los Angeles; available from http://www.acmi.canoe.ca/JamMoviesOscar/feb23_blacks.html; Internet; accessed 9 February 2000.

DGA Annual Employment Report. 1999. DGA Annual Employment Report Shows Women and Minority Hiring Down in 1998 [on line]. Available from http://www.dga.org; Internet; accessed 9 February 2000.

Due, Tananariue, and Allison Samuels. 2000. Where is the Love. Essence (February):8586.

Hispanic Congressional Caucus Entertainment Task Force. (1998). Findings [on line]. Available from http://www.imagen.org/caucusfindings.html; Internet; accessed 10 February 2000.

Hunt, Deryl G., 1998. Action Not Affirmed. Miami: ICB Productions.

Hunt, Deryl G., 1999. The Glass of Diversity. (pending publication by ICB Productions.)

Hunt, Deryl G., 1995. Miami: The Place Where Cultures Meet.

Miami: Spirit Productions.

Hunt, Deryl. G., Helen Ellison, and Lillian Hunt.1998. Understanding Culturally Different People: A Training Manual. Miami: Spirit Productions.

Hunt, Deryl G., 1995. When Two Cultures Meet. Miami: Spirit Productions.

O'Brien, Chris. 1999. NAACP Chief Speaks. [on line]. The News \& Observer; available from http://www.newsobserver.com/daily/1999/01/18/tri01.html; Internet; accessed 19 February 2000.

Reimer, Bennett. 1989. A Philosophy of Music Education. Englewood Cliffs, N.J. : Prentice Hall.

Seiderman, Arthur S., Steven E Marcus. 1989. 20/20 Is Not Enough. New York: Alfred A. Kouph, Inc.

Semas, Judith Harkham. 1996. Equality of Opportunity or Equality of Result [on line]. Available from http://hightechcareers.com/docs696/ethics696.html; Internet; accessed 19 February 2000. 
Shapiro, Harry L. 1971. Man, Culture, and Society. New York: Oxford University Press. 319-320.

Stanfield, John H. 1985. Theoretical and Ideological Barriers to the Study of Race -Making. Research in Race and Ethnic Relations, Vol.4, 161.

Tameran and Kemetic Religion. 1998. available from

http://www.radiant.org/bubastis/beliefs/tameran.html; Internet; accessed 27 January 2000

U.S. Commission on Civil Rights. 1970. Racism in America \& How to Combat It Urban Series No. 1 (January): 7.

Ward, Renee. (1976). Black Films, White Profits, The Black Scholar, Vol. 7, No. 8: 13-15.

Wright, Sharon D. (1999). Race and Civil Rights in the Contemporary Era, Policy Studies Journal, Vol. 27, No. 1; 171. 
APPENDICES 
Appendix 1

G.O.M.A ${ }^{19}$

Song and Cheer

The first phase of "The Glass of Diversity" module begins with a cheer. Members from the audience are selected to serve as cheerleaders. Each person will hold one of the following letters (G.O.M.A.) and (C.U.R.H.).

CALL

Give me a G.

Give me an $\mathrm{O}$.

Give me an $\mathrm{M}$.

Give me an $\mathrm{A}$.

What's the word?

What's the word?

What's the word?

What's the word?

\section{RESPONSE}

G. You got your G, you got your G.

$\mathrm{O}$. You got your $\mathrm{O}$, you got your $\mathrm{O}$.

M. You got your M, you got your M.

A. You got I, you got I.

G.O.M.A.

G.O.M.A.

G.O.M.A.

G.O.M.A.

$\mathrm{G}$ stands for GOAL

O stands for OBJECTIVE

$M$ stands for METHOD

A stands for ATTITUDE

WHAT IS OUR GOAL?

\section{Song}

Our goal is COMMUNITY. Building community in the spirit of working together.

Our objective is UNITY. We are unified around the ICB project.

Our method is RESPECT. We respect the rights and ways of life of others.

And our attitude is one of HONOR.

CALL

Give me an $\mathrm{H}$.

Give me an R.

Give me a $U$.

Give me a C.

\section{RESPONSE}

H. You got your $\mathrm{H}$, you got your $\mathrm{H}$.

$R$. You got your R, you got your R.

$\mathrm{U}$. You got your $\mathrm{U}$, you got your $\mathrm{U}$.

C. You got your $\mathrm{C}$, you got your C.

(To facilitate audience participation there should be posters with the following words community, unity, respect and honor.)

${ }^{19}$ The G.O.M.A. song is an adaptation of a previous work entitled, "University City Interface ProjectSong." This project is showcased in Deryl G. Hunt's book, Miami: The Place Where Cultures Meet. 
C stands for

$U$ stands for

$R$ stands for

$\mathrm{H}$ stands for
COMMUNITY

UNITY

RESPECT

HONOR

Song

We HONOR... We RESPECT... We are UNIFIED as a COMMUNITY.

COMMUNITY, UNITY, RESPECT and HONOR. 
Appendix 2

\section{G.O.M.A-CLOCK ${ }^{20}$}

Song and Cheer

The first phase of "The Glass of Diversity" module begins with a cheer. Members from the audience are selected to serve as cheerleaders. Each person will hold one of the following letters (G.O.M.A.) and (C.U.R.H.).

\section{CALL}

Give me a G.

Give me an $\mathrm{O}$.

Give me an $M$.

Give me an A.

What's the word?

What's the word?

What's the word?

What's the word?

\section{RESPONSE}

G. You got your $\mathrm{G}$, you got your $\mathrm{G}$.

O. You got your $\mathrm{O}$, you got your $\mathrm{O}$.

M. You got your M, you got your M.

A. You got I, you got I.

G.O.M.A.

G.O.M.A.

G.O.M.A.

G.O.M.A.

G stands for GOAL

O stands for OBJECTIVE

$M$ stands for METHOD

A stands for ATTITUDE

WHAT IS OUR GOAL?

\section{Song}

Our goal is COMMUNITY. Building community in the spirit of working together.

Our objective is UNITY. We are unified around the ICB project.

Our method is RESPECT. We respect the rights and ways of life of others.

And our attitude is one of HONOR.

CALL

Give me an $\mathrm{H}$.

Give me an R.

Give me a U.

Give me a C.

\section{RESPONSE}

H. You got your $\mathrm{H}$, you got your $\mathrm{H}$.

R. You got your R, you got your R.

$U$. You got your $U$, you got your $U$.

C. You got your $\mathrm{C}$, you got your C.

(To facilitate audience participation there should be posters with the following words community, unity, respect and honor.)

C stands for

\section{COMMUNITY}

${ }^{20}$ The G.O.M.A.-Clock remix edition is adapted from a current work by Deryl G. Hunt titled, "Just Telling Time." 
U stands for

UNITY

R stands for

RESPECT

$\mathrm{H}$ stands for

HONOR

\section{Song}

We HONOR... We RESPECT... We are UNIFIED as a COMMUNITY.

COMMUNITY, UNITY, RESPECT and HONOR.

*The next phase of G.O.M.A.-Clock uses six characters: person 1 (deep voice), person 2 (Islander), person 3 (Afro-American), person 4 (Haitian), person 5 (Hispanic), and person 6 (Caucasian).

Person 1: Our goal is community, building community by working together.

Person 2: Hold on man! What is this community thing? To me a community is where you live.

Person 3: The hood! Naw man, that maybe part of the community but it ain't the community man.

Person 2: $\quad$ It got to be community because we're united. You see people respect us because we have power. In the hood people are afraid to dis us... They honor our methods man.... They honor our methods....

Person 4: Let me tell you about community. Community works like the clock going round and round where every second, minute, and hour counts. No one element dominates; they are all included in time. The second, minute, and hour hands go around and around in love. Just telling time... Just telling time. Hey ahh... Jose (Maria-if a woman)... Jose (Maria)... do you think you can help me out here?

Person 5: Though diverse, they are united in a common good. The clock goes from diversity to unity and on to community as the three works in perfect harmony. The minute hand trusts the hour hand. The hour hand honors the minute hand. And the two respect the hard working second- always ticking, ticking, ticking and ticking...Just telling time, man. Just telling time.

Person 6: Community is like the clock going around and around, from diversity to unity and on to community because we trust, honor and respect each other in love. 
ALL: We go round and round in love. From diversity to unity to community.

Person 1: Can you dig it?

Person 2: I see... I see... I think I got it. Community really is like the clock. But there's still a little something missing here man. What about the numbers man? 1-2-3-4-5 . 6-7-8-9-10 .. 11-12. Twelve numbers on the clock. What do they mean? Do they have meaning at all? Can you tell me what this is about? This community thing?

Person 3: One stands for primary, it is the number of UNITY.

Person 4: $\quad$ Two stands for witness.

Person 5: Three stands for something greater than us all. It reaches deity.

Person 6: Every one knows that four stands for the four corners of the earth. North, East, South, and West.

Person 1: And five is the number of favor. Just telling time man... tick, tick, tick, just telling time... just telling time.

Person 3: Six is the last day of work.

Person 4: Seven is the day we rest.

Person 5: $\quad$ Eight is abundance.

Person 1: Nine is judgment.

Person 6: And Ten is the completion of all. Still telling time. The numbers on the clock going round and round. Telling time

Person 3: Eleven stands for imperfection.

Person 4: But Twelve... the number twelve stands for perfect government.

Person 5: The clock is covered by twelve numbers. Each working in conjunction with one another.

Person 6: The hands tell time. Just building community. Just telling time... community is like the clock going round and round from diversity to unity to community. Telling time... 
Person 2: You know man, there's something about this thing, its really something. You talk about moving from diversity to unity and on to community man. I like this community thing. I really got it now. I have experienced true community through this thing. Thank you, thank you all... Can I try it one time... one... two... three...

Give me a G. G. You got your G, you got your G.

Give me an $\mathrm{O}$. $\mathrm{O}$. You got your $\mathrm{O}$, you got your $\mathrm{O}$.

Give me an M. M. You got your M, you got your M.

Give me an A. A. You got I, you got I.

What's the word? G.O.M.A.

What's the word? G.O.M.A.

What's the word? G.O.M.A.

What's the word? G.O.M.A.

(Repeat the word GOMA until music fades.) 
Appendix 3

\section{Building Community Song}

\section{(Diversity)}

I am Variety

I keep company, with culturally different people

$$
\text { I am open to all things }
$$

You may know me, by one of my other names I'm known as a group, or division in classification

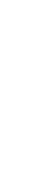

I know that you'll be there throughout all time

I can walk with you

I'd climb the great wall for you

We are building community

I can talk to you

I can call on you

$$
\text { We are building community }
$$

(Unity)

I am oneness

I am of the same kind

Though my color, age and gender

may differ

Think of me, as total harmony

Based on a set of beliefs

that respects the right ways of life

\section{CHORUS}

\section{(Community) \\ I am fellowship}

I enjoy working with others

I am willing to break bread

and share a drink with you

My goal is inclusive,

an omnipresent communion

where things are held in common

My desire is for mankind

CHORUS Repeat $2 x$ 
Appendix 4

OPPORTUNITIES AVAILABLE:

There is an Annual Entertainment Industry Job Fair, which provides workshops on jobsearch skills in entertainment and the opportunity to meet representatives from major studios, production companies and broadcasters. For more information contact Helen Hernandez at (213) 644-7965 or visit the web site at http://www.imagen.org (Sponsored by the Imagen Foundation.)

The Walt Disney Writers Fellowships seeks ethnically diverse talents not now in the industry by offering this one-year fellowship at a $\$ 33,000$ salary. For more information, contact: Fellowship Program Director, The Walt Disney Studios, 500 South Buena Vista Street, Burbank, CA, 91521-1735; or call (818) 560-6894.

The Walt Disney Television Directors Training Program is an 8-week apprenticeship for minorities who are already directors interested in learning multi-camera directing. It includes an eight-week apprenticeship and the opportunity to direct a TV show. For more information, contact: Television Directors Training Program, The Walt Disney Studios, 500 South Buena Vista Street, Burbank, CA, 91521-1735; or call (818) 560-1979.

Walt Disney offers a summer Feature Animation College Summer Program with opportunities in the following departments: the Animation Research Library, Artist Development, Business and Legal Affairs, Casting, Communications, Creative Development, Finance, Human Resources, Music and Production. For more information, contact Lisa Bach at (818) 558-2523.

The Director's Guild Assistant Directors Training Program provides diverse people with on-the-job training, supplemented by classroom seminars. For information about the Assistant Directors Training Program, please call (818) 386-2545 or see the Directors Guild of America's website, http://www.dgptp.org

The Latino Committee of the Director's Guild of America follows issues of importance to Hispanic Directors in the industry. They can be reached at (310) 289-5318.

$\mathrm{ABC}$ offers an Associates Program (for those who have college degrees and some level of experience in the television industry) which rotates people through various areas of the industry for 12-18 months. For more information, contact Judy Dorsey at (212) 456-6326.

$\mathrm{ABC}$ offers a News Development program (again for those with some experience in journalism) which places minorities in an affiliate for on-the-job learning. A development producer works closely with those in the program. For more information, contact Torrie Smith at (212)456-2667 .

$\mathrm{ABC}$ offers a Broadcast Training Program for college graduates who have studied 
communications or journalism to intern for one year at a radio or TV station. For more information, contact Judy Dorsey at (212) 456-6326.

The Time Warner Summer Hire Intern Program at Warner Brothers in Burbank provides ten weeks of exposure for high school and college students to careers at the studio. For more information contact Carol Katz or Benjamina Millado at (818) 954-1917.

The Warner Brothers Diversity Intern Program provides intern assignments in professional, technical, and clerical support positions. The assignments are paid, one-year terms. For more information, contact Benjamina Millado at (818) 954-1917.

The Warner Brothers Television Production Assistant Program offers minorities a general overview and exposure to a working atmosphere in television production, and provides entry-level training and skills needed for advancement in the industry. For more information, contact Benjamina Millado at (818) 954-1917.

A Feature Animation Intern Program at Warner Brothers exposes trainees to all facets of feature animation at WB Studio. The program targets minorities with a particular interest in the specialized area of film animation. For more information, contact Benjamina Millado at (818) 954-1917.

The Summer Tax Intern Program assists the Warner Brothers tax department with their workload to specifically expose minority students in the tax field to the business side of the entertainment industry. For more information, contact Benjamina Millado at (818) 954-1917.

A Feature Production Management Trainee Program exposes some minorities to the production process at Warner Brothers, as well as WB production policies and procedures. The 18-month, paid program ends with assistance in securing a full-time position at Warner Brothers. For more information, contact Benjamina Millado at (818) 954-1917.

The NBC Page Program brings young people into the New York television studio for errand-running and clerical work, and is a time-honored tradition of introducing young talent to the industry. For more information contact Judy Sullivan at (212) 664-2277.

NBC offers several Associates Programs of varying lengths and requirements, some of will rotate Associates and some of which require advanced degrees:

Broadcast and Network Operations Associate Program, (212) 664-2277;

Corporate Communications Management Associate Program, (212) 664-2277;

Entertainment Associates Program, (212) 664-2277; 
Management Associate Program, (513) 583-7340;

News Associate Program, (212) 664-2277;

TV Network Associate Program, (212) 664-2277; and

the TV Stations Division Management Associate Program, (212) 664-2277.

For more information about any of the Programs, contact the NBC Employee Relations Department at (212) 664-2277, or submit your resume to them at 30 Rockefeller Plaza, $16^{\text {th }}$ Floor, New York, NY 10112.

Universal offers an internship program open to college students, both paid and unpaid, to work in various parts of Universal Studios, in the movies, music, and the

business/financial divisions of the company. For more information, contact Sala Baker at (818) 777-1944 or Daria Hall (818) 777-1471.

The Emma L. Bowen Foundation for Minority Interests in Media offers a "Talent Bank" as a resource for all minorities (both students and professionals) seeking employment in the media industry. Additionally, their "Media Careers" program offers six years of academic and professional training for minority students as part of a Work-Study Program with a sponsoring company (which also provides salary and tuition funds). For more information about either program, contact the national office at (212) 456-1992, or the west coast office at (310) 557-7688.

Following are competitions for screenwriters; all have varying rules and awards (more information on these opportunities can be found at: www.moviebytes.com):

The New Professional Theater Wing Writing Festival seeks minority female writers and other writers of color writing full length dramatic work (plays and screenplays); there is no entry fee. For more information, contact Sherman Johnson (212) 290-8150.

The Nicholl Fellowships in Screenwriting are an international screenwriting competition for new writers, with up to 5 writers winning $\$ 25,000$ cash prize, and the writer agrees to write another screenplay. For more information, call (310) 247-3059 for a message about the program. (Sponsored by the Motion Picture Academy of Arts and Sciences).

The Breckenridge Screenplay Competition is open to writers who have not earned money writing for film or television ( $\$ 35$ entry fee). For more information, contact Julie Bullock (970) 453-6200, www.brecknet.com/bff/home.html or e-mail: filmfest@brecknet.com

The Top Dog Productions Screenplay Competition is open to any writer ( $\$ 30$ entry fee). For more information, call (602) 840-6414 or e-mail: topdogpro@aol.com 
The Television/Movie Script Competition is open to anyone ( $\$ 10$ entry fee). For more information, contact Leeanna Wesley, by fax, at (513) 531-1843.

The Nevada Screenwriters competition promotes screenwriting, and it is open to anyone ( $\$ 5$ entry fee). For more information, contact Joseph Wheeler at (702) 393-2141.

The Chesterfield Film Company Writer's Film Project seeks talented writers to compete for a $\$ 20,000$, one-year fellowship program in L.A. ( $\$ 39.50$ entry fee) For more information, call (213) 683-3977 or see: www.chesterfield-co.com

Script Connection's National Screenplay Competition offers talented writers a way to connect to the industry. ( $\$ 75$ entry fee, $\$ 50$ for starving artists/students) For more information, contact Marion Douglas (818) 623-7252, e-mail: marion1@pacbell.net or see: www.home.pacbell.net/marion1

Screen Credit Inc. and its associates seek to launch and promote careers within the entertainment industry. The competition is open to everyone ( $\$ 35$ entry fee). For more information, contact Shirley Hahn (888) 919-8191 or e-mail:

www.screencredit@earthlink.net

The competition for the King Arthur Screenwriters Award of \$1 million (divided among up to 10 winners) is held every other year to develop new talent (and work with established professionals) and intends to produce contest winners. The competition is open to everyone ( $\$ 55$ entry fee). For more information, call (410) 592-3466 or see: www.kingmanfilms.com

Maui Writers Conference Screenwriting Competition tries to bring new talent into the mainstream marketplace. It is open to everyone ( $\$ 35$ entry fee). For more information, contact Peter Scott at 2118 Wilshire Blvd., Suite 726, Santa Monica, CA 90403-5784; visit the web page: maui.net/ writers or e-mail: mauiscript@aol.com

The Massachusetts Film Office Screenwriters' Competition is open to all U.S. residents (no entry fee), but $85 \%$ of the script's locations must be authentic Massachusetts locations. For more information, contact Robin Dawson (617) 973-8800.

The Virginia Governor's Screenwriting Competition provides a forum for Virginia screenwriters and requires that $75 \%$ of the script must take place in Virginia. (No entry fee) For more information, contact Mary Nelson (804) 371-8204.

The Cinematexas International Short Film + Video + New Media Festival celebrates independent and student-produced short films with a competition and fall festival ( $\$ 15$ entry fee). For more information call Bryan Poyser at (512) 471-6497; visit the web page: uts.cc.utexas.edu/ cinematx - or e-mail: cinematx@uts.cc.utexas.edu 
The Slamdance Screenplay Competition supports new filmmakers on an ongoing basis ( $\$ 45, \$ 50, \$ 60$ entry fees). For more information, contact Peter Baxter at (213) 4661786 ; or see the web page: www.slamdance.com

The Elbow Film Soup Screenwriting Contest seeks feature length screenplays for development and possible production. It is open to everyone ( $\$ 30$ entry fee). For more information contact Katharina Smietana at: 292 North Street, \#1, Buffalo, NY 14201; or e-mail:kasia@localnet.com

The B.M.F. Productions' $1^{\text {st }}$ Annual Screenwriter's Contest is interested in producing and promoting the work of fledgling film makers. Eligibility is uncertain ( $\$ 35$ entry fee). For more information, contact Micah Ricke (612) 789-4926.

The Entertainment Employment Journal, a bimonthly publication which costs $\$ 35$ for 6 issues (in 1998), lists specific job opportunities as they occur. To subscribe, call (818) 901-6330.

The U.S. Directory of Entertainment Employers is published each year. Their web site is: http://www/eej.com/usdirinfo.html 
Appendix 5

Kawachi A. Clemons

Epcot Entertainment

Weekly Journal

January 18-21, 2000

\section{Tuesday}

- Reviewed Epcot Entertainment Resource Handbook to familiarize myself with day to day operations.

- Began looking through past production books. (Epcot Opening Celebration,)

- Sat with Scott Hill (Graphics, Technical Coordinator) to discuss CAD drawings for FIRST Robotics Competition to be held April 6-8, 2000.

- Discussed the FIRST project with Tom Ciupak (Ent. Mgr./Special Events).

- Assigned to work with Andy Warren (Ent. Mgr./Special Events) on entertainment for upcoming Cast Appreciation Day (1-20-00).

- Began reviewing production budget forms used at Epcot.

\section{Wednesday}

- Discovery Day- new cast member orientation to Epcot.

- Met with Andy to further discuss 1-20-00 event. Viewed stage set-up.

\section{Thursday}

- Cast Appreciation Day 5:30 am call

- Shadowed Andy

\section{Friday}

- Reviewed 1999 Black Heritage Celebration production book. Found useful information for this year's event.

- Scheduled to meet with Andy concerning this year's Black Heritage Celebration.

\section{Saturday}

- Event in American Adventure rotunda (breakfast).

\section{Thoughts for the week...}

This week has brought a clear understanding of maintaining a good production book. When done correctly, production books are a vital asset to those working on future events of a similar nature. The cast appreciation day provided good management experience. I quickly noticed that Andy was very meticulous in documenting all activities during the day. The day also provided a very touching experience. During the strike a fellow cast member approached me and thanked me for such a wonderful day. He also stated that, "Events like these are what makes working here so great. It shows that you all (management) really appreciate us (other cast). 
Tuesday

- Attended Special Events Production Meeting

- Attended Special Events/Conventions Joint Production Meeting

- Attended workshop: New Entertainment Management Countdown Program

\section{Wednesday}

- Event CIPO - International Graduation Ceremony

- Scheduled to walk roof of "China" for Chinese New Year Celebration (Feb. 5-7, 2000)

- Meeting in Odyssey Restaurant for Millennium Culinary Series Dinner-Scotland (Jan. 28-30, 2000)

- Production Meeting - Black Heritage Celebration

- Meeting - Tech Expo 2000

\section{Thursday}

- Research on possible design for Black Heritage (Adinkra Symbols-Africa)

- Rehearsal - Food \& Beverage Awards (Boardwalk)

\section{Friday}

- Event - Millennium Culinary Series (Scotland)

- Event - Millennium Culinary Series (Whisky demonstration)

\section{Thoughts for the week..}

This week was a step in the right direction. Waking up Tuesday morning I had a desire to attend a production meeting. So, I arrived to work a bit early $(8: 20 \mathrm{am})$. I was happy to see that a production meeting was scheduled in the conference room. I had the opportunity to meet the other members of the team (conventions). I ended the day by attending a management workshop.

Wednesday was a chilling day (It's freezing out here....). I experienced my first CIPO event. These events are held to give recognition to the international cast members. This day also gave an opportunity to meet with the creative forces behind Epcot events. I found it interesting to see the minds at work. While in this meeting the events team was trying to find a way to tie in food stations with various categories. I thought they should have taken advantage of having one in their midst who knew about African/Black culture. Considering this was a "Black Heritage" event. During the meeting I had an idea of possibly using Adinkra (African) symbols in the I for the Gala. I shared my thoughts with Andy after the meeting. I then proceeded to gather information on the symbols. It was just a thought maybe it will be used, maybe not. I can only offer my thoughts.

On Thursday I attended a rehearsal for the F\&B Awards. I found an inefficient use of time. Being that I have worked on these kind of shows in the past, I know that it is important to use time and resources wisely. There were non-entertainment people serving in certain entertainment capacities. It is my opinion that entertainment shows should be handled by entertainment people.

No more thoughts this week.... 


\section{Tuesday}

- Attended Gold Plate/Food \& Beverage Awards Rehearsal

- Viewed Black Heritage talent - Sisaundra Lewis (2 sets)

Wednesday

- Research on Blacks in History for BHC Gala I.

- Workshop - "How to take and Deliver Performance Notes"

Thursday

- Final Rehearsal \& Event - F \& B Awards

- Research on music from Barbados for BHC Gala

Friday

- Chinese New Year Celebration

Saturday

- same as above

Thoughts for the week...

I am beginning to have mixed thoughts about a possible future with this company. Every day I hear about someone either being fired, transferred, or demoted. As an intern one begins to wonder if there is room and/or a need to hire additional entertainment managers, production managers, producers etc.

I have not seen a great deal of effort put into the internship schedule. The schedule currently being used is one from the previous undergraduate intern. This schedule is centered around the concept of observation. This does not produce an extreme enlightening experience for me. As a mentee I have much to offer both professionally and creatively. The mentee should be seen as a learner and dispenser of knowledge obtained. As a result, last week I asked if I could attend some extra rehearsals that were not on my schedule. Since then I have been spending a great deal of time with George Koller (Show Director, Epcot Ent.). George involves me with his creative endeavors. In working with him I have been able to take my performance notes and discuss possible solutions that will enhance performances.

On last evening, (Wednesday) I heard that I would continue shadowing for the month of February. In March I will begin entertainment management duties. I spoke with Laurie (GM Epcot Entertainment) late Thursday evening. I expressed how pleased I was having worked with George. She said all I have to do is let her know if I'm not being challenged. We discussed future experiences at the new Millennium Village. Although her goal is to give me a well rounded experience, I gather that she knows this is a new endeavor for Epcot Entertainment. As we are the first, we will indeed encounter some challenges. I believe I should continue to inform her more on what works well and not so well. 
Tuesday

- Show - MK "Everyday's A Holiday"

- Picked up CD for BHC Gala

Wednesday

- Event - Kodak (Entertainment Canceled)

Thursday

- Event - VP Luncheon

- Event-Black Heritage Gala

Friday

- Event - Millennium Culinary Series (America - Black Heritage)

- Event - Millennium Culinary Series (Rum demo - Barbados)

Saturday

- Event - Millennium Culinary Series (America - Black Heritage)

- Event - Millennium Culinary Series (Rum demo - Barbados)

- Event - Millennium Culinary Series (Food and Wine tasting)

Thoughts for the week...

For the most part this week went very well. I got the opportunity to continue a bit of shadowing with George. We went over to MK to take a look at the "Everyday's a Holiday" show. George periodically views shows to ensure it maintains original intent. All of my events went by with no major problems. Overall I really enjoyed this week's past events.

February 15-19, 2000

\section{Tuesday}

- Homeroom meeting - Events \& convention team members gave update on last weeks events as well as upcoming events this week.

- Manager meeting - meeting with Michael Fletcher (Epcot Park Producer). Meeting was held to discuss the efficiency of the entertainment division. The meeting yielded very positive results. We were able to identify strong points as well as areas of improvement for the Special Event/Conventions department. Because of time constraints the meeting will continue at a latter date

- Show - Ko-Thi, African Dance Troupe (Am Gard Stage) - viewed their show. Gave Marilyn (Stage Manager) a possible solution to concerns regarding back drop. I suggested we use sand bags to off-set the unbalancing.

\section{Wednesday}

- Office Day - Reviewed all information for Mitsubishi event 
- Lighting Systems Design, Inc. (LSDI) - Went to LSDI to view laser demos of product and certain effects for FIRST event. Also discussed new show development concepts for the FIRST Awards show (April 8, 2000)

- Event - Mitsubishi (American Adventure). Entertainment to provide audio/lighting support for the Voices of Liberty performance as well as Mitsubishi Awards presentation..

Friday

- Office Day - Met with Peter regarding Event summary for the Mitsubishi event.

- Received and reviewed information for Sunday's events

- Met with Rick (technical coordinator) to learn more about BEO's (Banquet Events Order)

- Virgin - to pick up a few CD's for FIRST Awards laser show

\section{Saturday}

- Office Day - No events. Take care of office responsibilities.

- Millennium Village - view shows in the talent area.

\section{Thoughts for the week...}

This week went pretty well. Going over to LSDI was a real treat. I was able to behold the many possibilities of laser technology. I was also afforded an opportunity to participate in the Show Development process. I gave a brief run-down of ideas for a possible laser show for the first event. George and Tom loved my ideas. I believe they will incorporate some if not all of them (ideas). The event in AA rotunda went very well. We used The Voices of Liberty for entertainment. They are pretty good about doing their sets. All I had to do is inform them of set times and give a 5 minute call for each set. It's pretty amazing to see an event come together. These people (outside clients) spend obscene amounts of money for one evening of fun. I'm just glad to be a part of it all. Overall the client was extremely happy.

\section{February 20-24, 2000}

\section{Sunday}

- Event - Int'1 Paper Co. I served as entertainment manager for this event. The event was a reception and dinner function. Entertainment provided Mickey and Goofy characters.

\section{Monday}

- Meeting at Animal Kingdom - canceled

- Continued show development for FIRST finale event. Came up with transition to incorporate live dance in the show. Will present to George and fellows in tomorrow's meeting.

\section{Tuesday}

- Meeting - Briefly met with George to discuss my new show ideas. He loved them and wants to incorporate them into the show.

- Special Events/Convention Production Meeting Homeroom to give update on last week's events as well as upcoming events this week.

- Event - Seas VIP Lounge. I was called $30 \mathrm{~min}$ before the event. There was a schedule conflict that I was asked to relieve. The event was short, everything went fine.

- Recording - Voice Over, for American Gardens stage announcements.

\section{Wednesday}


- Office Day - No events. Take care of office responsibilities.

Thursday

- Event - CIPO Graduation

Thoughts for the week...

I got a lot accomplished this week. I feel a sense of rejuvenation. I got the opportunity to manage my first solo event. I had no problems, I was extremely confident that I could do the job. On Monday I continued to work on show development for FIRST finale ceremony. About a week ago George was trying to find a way to incorporate dancing into the show. I shared my new ideas with George, our show director. He loved the way I incorporated live dance into my script. He's going to schedule a meeting with Disney IDEAS to further discuss the project. On Tuesday one of the Conventions Managers had a scheduling conflict. I was asked to cover one the conflicting events in the seas VIP lounge. The staff is pretty confident with my ability to perform at a moment's notice. I have found that George has taken a great interest in me. He says I'm going to do well in this business. He's arranged for me to meet with Reggie Jarrett, Dir. Of Show Development and Production. I will be meeting him along with all the other Producers and Show Directors next Friday. The most important thing I gained this week is the ability to be ready and willing to perform the unexpected.

February 28-March 3, 2000

Monday

- Update for this evenings event. Contact SM for set time approval for tomorrow's event in China pavilion.

- Event - Farm Bureau Dinner (American Adventure). Entertainment to provide audio/lighting support for the Voices of Liberty performance as well as brief award presentation.

Tuesday

- Special Events/Convention Production Meeting Homeroom to give update on last week's events as well as upcoming events this week.

- Event - Sara Lee Corporation (China Pavilion). Entertainment to provide audio support for presentation. Talent for this evening is Si Zhu (Epcot)

\section{Wednesday}

- Office Day - No events. Take care of office responsibilities.

Thursday

- Entertainment Staff Meeting - Advance 2000, Discussed New Goals/Production Development for Epcot Entertainment.

\section{Friday}

- Event - Miami Dolphins (Odyssey). Entertainment to provide audio/lighting support.

Football Mickey and Cheerleader Minnie.

- Show Development and Production Meeting (Maingate)

\section{Thoughts for the week...}

Things have been very good this week. I got the opportunity to manage a few more solo events. It's quite interesting how everything comes together at Disney. I'm still amazed at the way we turn an empty room into a spectacular show. 
China's event yielded an extremely interesting situation. The sounds from the China Attraction bleed into the room during the 7:15 PM presenter. A few guests appeared to be a bit annoyed by the sounds. I contacted the China pavilion to see what options were available for future events. As a solution, I offered the possibility of pausing/muting a showing when there are events in the pre-show area that require presenters. China's manager agreed that this could be done on an individual client by client basis. Events/Sales will begin to use this method for all future events in China. I also provided the convention techs with an entertainment run down. They liked the notion of having a form that contained all pertinent ent. Info. They feel this makes their work a little easier by not having to sift through an entire BEO document.

Yesterday George told me that Epcot is going to incorporate my show development ideas in the FIRST closing ceremonies. That's a good thing!

The meeting for Friday has been changed to a social event this evening at PI. The staff would rather get together after hours to enjoy food and libations. I'll let you know what's up next week.

March 7-11, 2000

Tuesday

- Event - Tricon Restaurants (AA Rotunda) Entertainment to provide lighting and audio support. The band for this evening is self contained.

\section{Wednesday}

- Event - Coca-Cola (Met VIP) Entertainment to provide caricature art and a fortune teller. Entertainment scheduled to perform three alternating back to back sets.

- Event - Roche Vitamins (China Pavilion) Si Zhu to perform for dinner guests.

- Event - Lucent Technologies (Seas VIP) Entertainment to provide pianist for reception and dinner.

Thursday

- Office Day - No scheduled events. Take care of office responsibilities.

Friday

- Event - Millennium Culinary Series (Denmark)

- Event - Millennium Culinary Series (Beer Demo)

\section{Saturday}

- Event - Millennium Culinary Series (Denmark)

- Event - Millennium Culinary Series (Beer Demo)

- Event - Millennium Culinary Series (Dinner)

\section{Thoughts for the week...}

This week went by very fast. Maybe its because I was having so much fun. Monday's event was easy. The only challenge we encountered was with the band. The band's audio systern went out just before the 'after dinner' set. We (the techs) had to quickly round up a portable sound system. The guys were fast in recovering for this event.

Wednesday's events had me running all around. I had to manage three events in different venues. The trick was that they were running at the same time. Everything went well. 
Friday and Saturday brought another series of millennium culinary events. The event run downs are the same as previous ones. Food tasting and Beverage sampling in the afternoon, followed by a dinner/reception in the evening. This month we acquired a string quartet to entertain the guests.

March 13-17, 2000

Monday

- Office Day - No scheduled events. Take care of office responsibilities.

- Meeting - Epcot Events to discuss future events to be held in the park

Tuesday

- Office Day - No scheduled events. Take care of office responsibilities.

- Special Events/Convention Production Meeting Homeroom to give update on last week's events as well as upcoming events this week. (canceled)

Wednesday

- Recording session to set FIRST finale music to time code.

- Town Hall Rehearsal and Load In

- Meeting with Ted Ricketts to discuss future projects.

Thursday

- Event - Salaried Town Hall Meeting - Meeting held by George Kalogridis, Epcot VP. The meeting addressed present and future statistics of Epcot.

Friday

- Show Development and Production Meeting (Maingate)

- Meeting with Reggie Jarrett

Thoughts for the week...

This was another good week. Monday's meeting was extremely informative. The staff worked on resolving possible venue conflicts as well as ways to off set costs. One problem encountered was a double booking. There was a wedding scheduled in a room that would be used for rain back up. The wedding was ok as long as it did not rain on the day of the event. So we had to explore other options. The only option was to rent a tent. There were no other available venues to hold $300+$ people. One problem, the tent is not in the projected budget. Solution: offset cost of the tent by scheduling another event the day after in the same tent. This is being looked into. Later this month we have another big event is coming up (D\&G perfume). It's gong to be great working with the creative people from this company. The recording session with Ted Ricketts went extremely well. We were able to set all of our music to time code with no major problems.

Thursday's town hall was excellent. Entertainment provided an outstanding package demonstrating its limitless capabilities. The package involved audio, moving lights, and an $\mathrm{A} / \mathrm{V}$ power point and video presentation. American Vybe provided live vocal entertainment.

I believe I'm doing extremely well here. Every time I introduce myself to someone in management/executive status they already know who I am. Everyone says that they have been hearing good things about my performance with the Epcot team. In fact, quite a few people have asked to meet with me to get to know me better and talk about my future in the production business. 
March 20-24, 2000

\section{Tuesday}

- Special Events Production Meeting to give update on last week's events as well as upcoming events this week.

- Special Events/Convention Production Meeting Homeroom to give update on last week's events as well as upcoming events this week.

- LSDI - went to their facility to check out options of using an invisible screen for FIRST Finale laser show.

\section{Wednesday}

- FIRST Finale Production Meeting - Meeting involved Disney i.d.e.a.s., Special FX Design, LSDI, and Epcot Ent. Teams. The purpose of the meeting was to ensure all elements of the show maintain cohesiveness.

Thursday

- Event - CIPO Graduation

Friday

- Office Day

- Meeting with Michael Korkis, Epcot Show Director

\section{Thoughts for the week...}

The only thing I really got from this week was something almost indescribable. In the meeting on Tuesday I was so amazed to see and hear the minds of a room full of creative people at work. And just to think, I was right there with them putting in my two cents. Amazing!! Two years ago who would have thought I would be in this position. The meeting with Michael went really well. Michael was really impressed with the works I have been involved with in the past few years. He says that is a good thing, considering few people impress him. He appears to feel really good about having me here this semester.

March 27-31, 2000

\section{Monday}

- Event - Dolce \& Gabbana. Entertainment provided a vocal duo, the sage of time, and audio and lighting package.

\section{Tuesday}

- Special Events Production Meeting to give update on last week's events as well as upcoming events this week.

- Special Events/Convention Production Meeting Homeroom to give update on last week's events as well as upcoming events this week.

- Viewed entertainment talent in the park.

\section{Wednesday}

- Office Day - No Events. 


\section{Thursday}

- Office Day - No Events.

Friday

- Office Day - No Events.

\section{Thoughts for the week...}

I must say that looking in retrospect I have been extremely fortunate to have worked on so many huge projects. The level of presentation for the $D \& G$ event was amazing. There were illuminated columns, and center pieces that changed colors during the event. The tables illuminated D \&G's new extremely revealing ad. The lighting package was Vari-lite, nuff said. And to top it off, audio used a Myer Sound system to enhance the existing house system. It's amazing what can be done for the right price.

Our Tuesday meeting revealed the new Disney look guidelines. Men can now wear a mustache but you can't grow one... interesting.

Overall this week was pretty slow. Having no major events allowed the team to catch up on work, reports, and prepare for next month's events.

April 4-8, 2000

Tuesday

- Special Events Production Meeting to give update on last week's events as well as upcoming events this week.

- Special Events/Convention Production Meeting Homeroom to give update on last week's events as well as upcoming events this week.

- Rehearsal - FIRST

\section{Wednesday}

- Meeting with Thomas to fill out cast member evaluations.

- Meeting with Chip Koch to discuss the internship.

\section{Thursday}

- Meeting - Breakfast with Ron Logan.

- FIRST opening ceremonies and practice rounds.

\section{Friday}

- FIRST $-1^{\text {st }}$ day of competition.

\section{Saturday}

- FIRST $-2^{\text {nd }}$ day of competition

- Semi-Final and Final Rounds

- Closing ceremonies

\section{Thoughts for the week...}

Participating in this event I was able to see again how good the special events performs. The hours reminded me of last year's Academy Awards. There was a need for an additional stage manager, naturally I agreed to take on the job. Tom (Production Mgr) felt really good about giving me the task. I was to oversee three competition playing fields, all running at the same time. At times there was audio and video 
being sent to and from my stages to the main stage. I believe the training/experience received over the past two years prepared me to perform an outstanding job.

The finale was extremely well received. Everyone marveled over the impact, excitement, and overall energy of the show. George Kalogridis, VP, Epcot was also very impressed. I remember the first day George, Tom, and I went over to LSDI to see what possibilities there were for lasers in the finale show. I remember giving lots of ideas from the time of conception. It was nice to see some of my ideas put to the screen. I am happy I got the chance to experience this event. 


\section{APPENDIX 6}

Author: Tracey O. Jones at DISNEX-WDW-CELEBd

Dace:

$3 / 1 / 00 \quad 10: 10 \mathrm{AM}$

TO: AndY Anderson at DISNEY-WDW-ECMAC, TOM Ciupak at DISNEX-WDW-ECPRODA,

Peter M. Gibson at DISNEY-WDW-ECPROD1, Heather King at DISNEY-WDW-ECPRODI,

Tim Lauterbach at DISNEY-WDW-ECPRODI. John MCFarlane at DISNEX-WDW-ECPRODL.

WAURIE SPEIGHTS at DISNEX-WDW-ECCAST2. ThOmaS TEYOn at DISNEX-WDW-INNOVTNS1,

Andy warxen at DISNEY-WDW-ECPROD1, Ann Willians at DISNEY-WDW-INNOVINS1.

Kawacbi A. Clemons at DISNEY-WDW-ECPROD1. Michael Fletcher at DISNEY-WDW-ECPROD1

Subject: Re(2): Entercainment Recap: Saxa lee 2-29-00

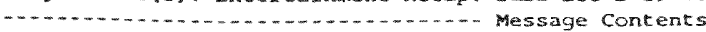

This is excellent feedback... in the future, please read the agenda section of the BEO closely, as it should always list exactly what's happening and when. In this particular instance, it was noted on the BEO that the speaker would make remarks beginning at $7: 15 \mathrm{pm}$. This should have sent a red $f$ lag as it relates to the attraction shows and timing. If you could, please send me the times and the length for the China show and $I$ * 11 make sure $I$ forward that information to the other services managers on my team. Thanks again Kawachi for a job well

done; the elient has given great feedback regarding your appearance. attitude and professionalism.

Tracey 0 .

$828-2627 / 5 \%(6)$

Reply Separator

Subject: Re: Entertainment Recap: Sara Lee $2-29-00$

Author: Michael Fletcher at DISNEX-WDW-ECPRODI

Date: $3 / 1 / 009: 37$ AM

Kawachi.

Thank you for your observation regarding the timing with the

attraction. Is that a note we can give sales when booking this venue?

Thasks.

Michael

Reply Separator

Subject: Entertainment Recap: Sara Lee 2-29-00

Author: Kawachi A. Clemons at DISNEY-WDW-ECPRODL

Date: $2 / 29 / 009: 02 \mathrm{PM}$

Event Name: Sara Lee Comp.

Event Date: 02/29/2000

Event staxt: $6: 30 \mathrm{PM}$

Event End: $8: 30 \mathrm{FM}$

Location: China Pavilion

Account Manager: Tracey o. Jones

Entertainment Managex: Kawachi clemons

Tonight's Event was Fantastic Because:

This event was great because it afforded guests the opportunity to

experience authentic music of the chinese culture.

Challenges we encountered:

The sounds from the China Attraction bleed into the room during the 7:15 RM presenter. A few guests appeared to be a bit annoyed by the sounds.

Rey Learning"s For Next Time:

schedule possible presenters after the last attraction showing.

Overall Event Notes:

overall Great Event.

CC: Event File 